\title{
O RACJONALNOŚCI PRZEKONAŃ ŚWIATOPOGLĄDOWYCH W UJĘCIU RYSZARDA KLESZCZA
}

\section{Uwagi wstępne}

W bogatej i wieloaspektowej działalności badawczej Ryszarda Kleszcza ważną rolę odgrywają rozważania z zakresu epistemologii i metafilozofii. Rozważania te mają charakter zarówno historyczny, jak i systematyczny. Jednymi z problemów wiodących podejmowanych w ramach dociekań epistemologicznych i metafilozoficznych są naukowość filozofii, stosunek filozofii do światopoglądu oraz zagadnienie racjonalności tez filozoficznych i światopoglądowych ${ }^{1}$. Podejmowana przez Kleszcza problematyka oraz analityczny styl prowadzonych przez niego dociekań zaświadczają dobitnie o jego ścisłym związku z tradycją Szkoły Lwowsko-Warszawskiej (dalej SLW), której jest nie tylko wybitnym znawca, ale i której fundamentalne postulaty metafilozoficzne sam realizuje. Jednym $\mathrm{z}$ takich postulatów metafilozoficznych jest postulat racjonalności filozofii, wyrażany niejednokrotnie przez Kazimierza Twardowskiego i jego wybitnych uczniów (Woleński 1985). Racjonalizm należy tu rozumieć w sensie zaproponowanym przez Kazimierza Ajdukiewicza jako antyirracjonalizm, czyli „logiczny racjonalizm" sprowadzający się do postulatu, żeby uznawać tylko takie przekonania, które są jasno w języku wyrażone (jednoznaczne), dla których istnieje odpowiednie uzasadnienie (racje) i które podlegają intersubiektywnej procedurze sprawdzenia, czyli możliwa jest ich weryfikacja lub falsyfikacja

${ }^{1} \mathrm{~W}$ niniejszym artykule będziemy posługiwać się na ogół zamiennie terminami takimi jak „teza”, "przekonanie” czy „twierdzenie”, za wyjątkiem kontekstów, w których konieczne jest precyzyjne i wyraźne rozróżnienie tych terminów. Przekonanie zawsze wiąże się z formą zaangażowania w uznanie prawdziwości, czyli zakłada stosunek pewnego podmiotu do określonych treści propozycjonalnych. Zakładamy, że z kontekstu, w którym terminy powyższe będą używane, można będzie bez trudu wywnioskować, czy chodzi o przekonanie w sensie uznawanego przez kogoś twierdzenia czy tezy, czy tylko o pewną treść propozycjonalną nieobjętą aktem asercji. 
(Ajdukiewicz 1934). Wypowiedzi niejasne, wieloznaczne i generujące sprzeczności nie mają wartości poznawczej, nie mogą być uznane za racjonalne i jako niesprawdzalne pozostają poza kontrolą intersubiektywnej wspólnoty badawczej i komunikacyjnej. W XX w. opracowano bardzo surowe kryteria racjonalności i sensowności wypowiedzi, w tym i takie, które za bezsensowne i bezwartościowe poznawczo uznawały wszelkie zdania i przekonania w nich wyrażane, niedające się empirycznie zweryfikować (Koło Wiedeńskie) lub sfalsyfikować (Karl Popper). W ten sposób nie tylko twierdzenia metafizyki, etyki czy prawa, ale i wszelkie przekonania światopoglądowe i religijne były oceniane jako bezsensowne i poznawczo bezwartościowe. Skrajny empiryzm neopozytywistyczny implikował scjentystyczną metafilozofię $w$ tym sensie, że uznawał, że prawo bytu w racjonalnej dyskusji mają wyłącznie twierdzenia nauk przyrodniczych, a narzędziem ich porządkowania jest logika rozumiana jako zbiór pustych informacyjnie schematów, których treścią mogą być wyłącznie treści zdań empirycznie sprawdzalnych. Tego skrajnego scjentyzmu nie podzielano w SLW, do której programu metafilozoficznego nawiązuje Kleszcz (2013). Jednakże stojąc na gruncie antyirracjonalizmu SLW i zdecydowanie dystansując się od scjentystycznego, antyfilozoficznie nastawionego skrajnego empiryzmu neopozytywistów, Kleszcz wypracował, w naszym przekonaniu, własna, oryginalną na gruncie polskim koncepcję racjonalności przekonań2. Jest to koncepcja subtelna, wieloaspektowa i osadzona, jak powiedzieliśmy, w tradycji SLW, ale też wykraczająca poza ramy tej szkoły, uwzględniająca problemy i stanowiska obecne w najnowszej epistemologii, ale sięgająca też do analiz i wyników wcześniejszych tradycji i szkół filozoficznych, aktywnych przed powstaniem SLW. W refleksji Kleszcza szczególnie ważną rolę wydają się odgrywać poglądy konwencjonalistów francuskich oraz scholastyków, wysoko cenionych np. przez Jana Łukasiewicza, a raczej niedocenianych przez Twardowskiego (Łukasiewicz 2013; Twardowski 1910). Te liczne i zróżnicowane źródła inspiracji, z których wyrasta koncepcja racjonalności Kleszcza, świadczą nie tylko o erudycji omawianego w tym tekście Autora, ale również o jego otwartości na różne filozoficzne tradycje, z których potrafi on wydobyć wartościowe składniki i z których następnie konstruuje własne pojęcie racjonalizmu epistemicznego i metafilozoficznego.

Nie wchodząc w szczegółową egzegezę i interpretację licznych pism Kleszcza, w niniejszym tekście postaramy się przedstawić i obronić tezę,

${ }^{2}$ Koncepcja ta jest rozwinięciem i modyfikacją poglądów Twardowskiego (1929/1965) oraz w szczególnym stopniu Izydory Dąmbskiej (1938), ale nawiązuje również do prac i idei przedstawicieli Koła Krakowskiego, Józefa Marii Bocheńskiego i Jana Salamuchy (1997). Nie możemy tych wzajemnych powiązań i inspiracji przedstawić szczegółowo w tym tekście, ale z pewnością warto o tym historycznym kontekście pamiętać. 
że wypracowane przez niego poglądy pozwalają uznać możliwość istnienia racjonalnego światopoglądu, przy czym racjonalny światopogląd nie tylko nie musi być naukowy, ale i wręcz nie może być światopoglądem naukowym. Przez światopogląd rozumiemy, podobnie jak Kleszcz, zbiór przekonań obejmujących naturę i pochodzenie świata i człowieka, sens i wartość ludzkiego życia, ostateczny cel ludzkiego życia i historii poszczególnych narodów i świata. Tak pojęty światopogląd nie może być naukowy w tym sensie, że żadna z nauk przyrodniczych ani ścisłych, ani ogólnie biorąc „nauk szczegółowych”, nie czyni przedmiotem własnych dociekań zagadnień światopoglądowych. Nauki szczegółowe mogą mieć i faktycznie mają znaczenie przy formowaniu zarówno poszczególnych przekonań światopoglądowych, jak i przy ocenie ich racjonalności, o czym będzie mowa poniżej, ale nie można wyłącznie z twierdzeń naukowych żadnego światopoglądu w podanym wyżej sensie uformować.

\section{Racjonalność epistemiczna}

Ryszard Kleszcz posługuje się pojęciem racjonalności epistemicznej, która to racjonalność jest stopniowalna, stąd można jego koncepcję nazwać gradualistyczną. Przynależność danego przekonania do klasy przekonań o określonym stopniu racjonalności wiąże się ze spełnianiem lub niespełnianiem określonych warunków czy kryteriów racjonalności właściwych dla przekonań określonego rodzaju. Stopniowalność racjonalności przekonań implikuje istnienie ich hierarchii. Najbardziej racjonalne lub w najwyższym stopniu racjonalne są przekonania naukowe, a wśród nich te, dla których istnieje konkluzywny dowód ich prawdziwości. Przekonania takie są wiedzą (wiedzą naukową), ponieważ zostały uzyskane dzięki zastosowaniu metod właściwych dla danego rodzaju nauki. Ten stopień racjonalności przysługuje jednakże tylko twierdzeniom logiki i matematyki dowiedzionym w sposób właściwy dla tych nauk.

Przekonania należące do nauk o świecie leżącym w zasięgu intersubiektywnie sprawdzalnego i komunikowalnego doświadczenia posiadają niższy stopień racjonalności niż twierdzenia logiki i matematyki, ponieważ nie są uzyskane w wyniku dedukcyjnych rozumowań, ale na podstawie różnego rodzaju obserwacji, eksperymentów, pomiarów itp., których wyniki podlegają uogólnieniu $\mathrm{w}$ ramach rozumowań indukcyjnych. Dopuszczalne są oczywiście w naukach empirycznych rozumowania dedukcyjne, ale są one użyteczne bardziej w procedurach falsyfikujących niż weryfikujących (dedukcjonizm Poppera). Metoda dedukcyjna w naukach empirycznych służy co najwyżej do eliminacji fałszu, a nie do ustalenia prawdy jako wyniku konkluzywnego wnioskowania. 
Odrębną klasę przekonań stanowią przekonania tworzące wiedzę potoczną (common knowledge), która różni się od wiedzy naukowej stosowanymi metodami pomiaru, przedmiotem badań i ścisłością sformułowania jej wyników. Przekonanie, że na stole stoi filiżanka, jest racjonalne, jeśli jest uzyskane za pomocą obserwacji i na tej podstawie uznane za prawdziwe. Nie można jednak powiedzieć bez zastrzeżeń, że wiedza potoczna jest wiedzą tej samej siły i rangi co wiedza logiczno-matematyczna i przyrodnicza. Niewątpliwie jednak podlega ona intersubiektywnemu sprawdzeniu i jest komunikowalna.

Niższy i słabszy stopień racjonalności posiadają przekonania czy tezy filozoficzne, w tym metafizyczne. Przekonania metafizyczne nie są sprawdzalne w tym samym stopniu i tymi samymi metodami co przekonania naukowe i potoczne. Nie są one jednak pozbawione wartości poznawczej, podlegają ocenie logicznej oraz można oceniać siłę racji za nimi przemawiających i argumenty przeciwko nim.

Niższy jeszcze stopień racjonalności niż tezy filozoficzne posiadają przekonania światopoglądowe. Przekonanie, że światem kieruje potężna siła (Opatrzność Boża) i że wszystko, co się wydarza, jest dobre lub jeśli jest złe, to prowadzi do dobra, którego natury i wielkości nie jesteśmy w stanie $\mathrm{w}$ życiu doczesnym pojąć, jest przekonaniem światopoglądowym, jeśli ktoś uznaje je za własne, a nie tylko traktuje jako ogólną hipotezę metafizyczna, którą rozważa jako jedną z możliwych opcji. Przekonaniem światopoglądowym jest też każdy z dogmatów religii chrześcijańskiej czy innej religii.

Z każdym ze stopni racjonalności jest związany zbiór kryteriów racjonalności. Warunkiem koniecznym racjonalności wszelkich rodzajów przekonań jest ich niesprzeczność. Przekonanie racjonalne nie implikuje żadnych sprzecznych przekonań i samo nie wchodzi w sprzeczność z innymi uznanymi wcześniej przekonaniami. Kleszcz mówi, za Christopherem Cherniakiem (1986), o minimalnej inferencyjnej racjonalności, polegającej na zdolności do wykrycia i usunięcia przekonań generujących sprzeczności oraz zdolności do wyprowadzenia z uznanych już przekonań innych przekonań (Kleszcz 2007, s. 13). Zatem każde przekonanie racjonalne epistemicznie musi być niesprzeczne (wewnętrznie i zewnętrznie). Sugestia, że podmiot żywiący pewne przekonania powinien wykazać zdolność do wyprowadzania z nich innych przekonań (niesprzecznych), może skłaniać do wniosku, że w najbardziej zoptymalizowanej wersji minimalnym warunkiem racjonalności każdego przekonania jest spójność (koherencja), a nie jedynie niesprzeczność. Mając na uwadze jednak, że głównym przedmiotem naszych zainteresowań $\mathrm{w}$ tym tekście jest racjonalność przekonań światopoglądowych i filozoficznych, można i należy uznać, że niesprzeczność z teoriami współczesnej nauki jest koniecznym warunkiem racjonalności tego typu przekonań. Spójność może mieć 
wartość przy ocenie stopnia racjonalności danego przekonania w ramach określonego rodzaju przekonań pozanaukowych w ramach ich systemu. Dla przykładu można się zastanawiać nad spójnością dwóch następujących niesprzecznych ze sobą przekonań w ramach światopoglądu religijnego: istnieje wszechmocny Bóg - istnieją zdarzenia niemające wyjaśnienia naukowego (cuda).

Przekonania niesprzeczne, dla których istnieje konkluzywny dowód ich prawdziwości, są w najwyższym stopniu racjonalne i stanowią wiedzę. Jak była już o tym mowa, ten warunek spełniają tylko przekonania stanowiące wiedzę logiczna i matematyczną. W wypadku przekonań należących do nauk szczegółowych kryterium ich racjonalności rozstrzygające o tym, że mają one wysoki, choć nie najwyższy stopień racjonalności, jest ich empiryczna sprawdzalność, która może polegać albo na wykazaniu wysokiego prawdopodobieństwa ich prawdziwości, co jednak nie jest nigdy gwarancją niezawodną prawdziwości, albo na wykazaniu ich fałszywości (falsyfikacji). Przekonania (ogólne hipotezy, teorie) naukowe podatne na falsyfikację są $\mathrm{w}$ większym stopniu racjonalne niż przekonania niedające się sfalsyfikować ani tym bardziej zweryfikować. Zatem kryterium wysokiej racjonalności przekonań stanowiących wiedzę naukową o świecie leżącym w zasięgu doświadczenia ludzkiego stanowi podatność na falsyfikację lub weryfikację. Podobnie stopień racjonalności przekonań stanowiących wiedzę potoczną jest zależny od możliwości ich sprawdzenia (potwierdzenia lub obalenia).

Tezy filozoficzne posiadają niższy stopień racjonalności, są słabiej racjonalne (Kleszcz 2013) niż przekonania naukowe czy przekonania tworzące wiedzę potoczna, ponieważ nie są w tym samym stopniu sprawdzalne $^{3}$. Nie podlegają uprawdopodobnieniu przez mnożenie obserwacji konfirmujących ani też nie są zasadniczo falsyfikowalne. Zakres ich badania niejednokrotnie, choć nie zawsze, wykracza poza metody obserwacyjne nauk empirycznych. Warto jednak dodać, że przekonania filozoficzne mogą różnić się siłą argumentów czy racji przemawiających za nimi lub przeciwko nim, o czym poniżej będzie mowa. Choć zatem wszelkie przekonania filozoficzne posiadają niższy stopień racjonalności niż wszelkie przekonania naukowe, to jednak i w ramach filozofii można stosować pewne oceny porządkujące status epistemiczny poszczególnych tez, wskazując na rangę racji przemawiających za lub przeciw pewnej tezie.

Status epistemiczny przekonań światopoglądowych jest najniższy, ponieważ nie wymaga się od nich, by posiadały racje właściwe dla tez filozoficznych, nie mówiąc o wymogach sprawdzalności stawianych

${ }^{3}$ O różnicy pomiędzy wiedzą naukową a potoczną pisze szczegółowo Władysław Tatarkiewicz (1971). 
przekonaniom naukowym. Warunkami racjonalności przekonań światopoglądowych są ich wewnętrzna spójność oraz niesprzeczność z przekonaniami naukowymi ${ }^{4}$. Jeśli przekonanie światopoglądowe jest sprzeczne z nauka, zdaniem Kleszcza nie jest racjonalne, nawet jeśli jest niesprzeczne z innymi przekonaniami światopoglądowymi danej osoby (Kleszcz 2013). Zatem wewnętrznie spójny, ale sprzeczny z nauką światopogląd jest nieracjonalny i jest to jego wada epistemiczna. Można powiedzieć, że nauka jest „normą negatywną" dla światopoglądu (w tym np. dla religii i teologii) ${ }^{5}$. Niski stopień racjonalności światopoglądu w relacji do filozofii bierze się również stąd, że przekonania światopoglądowe są zwykle, choć nie zawsze, nabywane przez tradycję i na podstawie autorytetu. Osoba wyznająca światopogląd katolicki, czyli wierząca np. w istnienie Boga i uznająca dogmat trynitarny, nie doszła do tego przekonania sama po namyśle, rozważeniu wszystkich racji za i przeciw, ale zostało jej to podane do wierzenia przez Kościół, który z kolei za uzasadnienie swoich dogmatów bierze objawienie zawarte w Biblii. Nie każdy światopogląd musi być uznany na mocy autorytetu i nabyty dzięki tradycji. Możliwy jest światopogląd uformowany $\mathrm{w}$ wyniku indywidualnych, wieloletnich niekiedy wysiłków intelektualnych i rozważań. Światopogląd taki może być nazwany filozoficznym, może zarówno być naturalistyczny (ateistyczny), jak i teistyczny (supranaturalistyczny). W obu przypadkach jednakże jego tezy są nierozstrzygalne środkami dostępnymi nauce. Niższy stopień racjonalności przekonań światopoglądowych w stosunku do tez filozoficznych można wyjaśniać również tym, że tezy filozoficzne są stale poddawane różnego rodzaju testom i próbom, podczas gdy światopogląd jest stosunkowo trwałym i uznawanym z większym stopniem asercji zbiorem

${ }^{4}$ Kleszcz mówi też niekiedy o „racjonalności minimalnej”, której warunkami są eliminacja sprzeczności i zdolność wyprowadzania pewnych konsekwencji logicznych z uznawanego przez siebie zbioru przekonań. Ten ostatni warunek określa jako warunek minimalnej inferencji. Oba podane warunki są minimalne, ponieważ nie zakłada się, że podmiot żywiący dany zbiór przekonań jest zobowiązany wyeliminować wszystkie rzeczywiste sprzeczności, o ile takie występuja, ani też nie zakłada się, że jest zobowiązany wyprowadzić wszystkie logiczne konsekwencje możliwe do wyprowadzenia z uznawanego zbioru przekonań. Chodzi jedynie o to, by podmiot żywiący przekonania minimalnie racjonalne umiał dedukcyjnie wyprowadzić jakiekolwiek konsekwencje logiczne ze swoich poglądów (Kleszcz 1998, s. 116-117).

${ }_{5}$ Pojęcie normy negatywnej występuje w teologii i polega na tym, że teza ( $w$ tym nawet naukowa) sprzeczna $\mathrm{z}$ wiarą powinna być przez osobę wierzącą i uznającą daną wiarę (religijną) odrzucona (Salamucha 1997a). W epistemologii Kleszcza norma negatywna ma inną postać: teza wiary (religii) sprzeczna z wiedzą naukową powinna być odrzucona. Teza ta jednakże nie implikuje radykalnego scjentyzmu, przeciwnie, jak będziemy argumentować w ostatniej części naszego artykułu, daje się ona utrzymać przy założeniu tezy metafizycznej teizmu, do której uznania skłania się Autor dyskutowanej koncepcji racjonalności przekonań. 
przekonań. Innymi słowy, przekonania światopoglądowe, o ile spełniają warunek niesprzeczności oraz minimalnej inferencji, są najsłabiej racjonalne, ponieważ są uznawane $\mathrm{z}$ siłą asercji nieproporcjonalną do siły racji i świadectw przemawiających za tego rodzaju przekonaniami. Choć Kleszcz nie posługuje się terminem „ewidencjalizm” w swoich analizach epistemologicznych, jego koncepcję racjonalności epistemicznej można właśnie nazwać koncepcją ewidencjalistyczną ${ }^{6}$ Zarazem - jak zauważa filozof, idąc tropem Twardowskiego - przekonania światopoglądowe odgrywają niezwykle doniosłą rolę aksjologiczną i egzystencjalną kierują bowiem zachowaniem jednostek oraz sposobem, w jaki ludzie interpretują świat i swoje życie (Kleszcz 2013).

Bardzo ważne w kontekście rozważań nad racjonalnością przekonań jest rozumienie pojęcia wiary. Kleszcz proponuje trzy znaczenia terminu „wiara". Są one następujące:

(A) wiara w szerokim sensie, obejmująca przekonania, o których nie można powiedzieć, że są prawdziwe i uzasadnione w sposób dopuszczalny w naukach formalnych lub empirycznych;

(B) wiara w sensie węższym, obejmująca przekonania, których przedmiotem nie są fakty leżące $\mathrm{w}$ zasięgu naszego empirycznego doświadczenia i które nie mogą być uzasadnione za pomocą metod stosowanych w naukach szczegółowych opartych na obserwacjach i eksperymentach;

(C) wiara $\mathrm{w}$ znaczeniu religijnym, w zakres której wchodzą przekonania należące do credo określonych religii (Kleszcz 2013, s. 178).

Oczywiste jest, że wiara $\mathrm{w}$ każdym $\mathrm{z}$ trzech powyższych znaczeń może być racjonalna, ponieważ może spełniać uniwersalny i konieczny warunek racjonalności, jakim jest niesprzeczność. Należy dodać, że koherencja nie jest w ujęciu Kleszcza gwarancją prawdziwości przekonań ani też nie stanowi ich uzasadnienia. Uzasadnione jest bowiem tylko to przekonanie, dla którego istnieje intersubiektywnie sprawdzalne i wyrażalne w języku zrozumiałym powszechnie (a przynajmniej dla kompetentnych badaczy) empiryczne świadectwo. Przy czym empiryczna sprawdzalność nie sprowadza się tu do weryfikacji, ale polega na istnieniu możliwości empirycznej falsyfikacji danego przekonania na podstawie określonych danych empirycznych. Racjonalność, prawdziwość i uzasadnienie nie są więc pojęciami równoważnymi zakresowo ${ }^{7}$. Należy też odnotować,

${ }^{6}$ O koncepcji ewidencjalizmu pisze w literaturze polskiej Ewa Odoj (2015).

7 Powtórzmy, ponieważ uważamy to za istotny składnik omawianej koncepcji: koherencja jako warunek racjonalności przekonania nie stanowi jego uzasadnienia. Uzasadnieniem dla danego przekonania może być w zależności od jego rodzaju: dowód typu dedukcyjnego, rozumowanie indukcyjne, argumentacja do najlepszego wyjaśnienia, sprawdzalne i wyrażalne $\mathrm{w}$ języku doświadczenie lub inne jeszcze racje uznania przekonania za prawdziwe. 
że wiara w sensie (A, B, C) ma według Kleszcza charakter propozycjonalny (wiara, że...). Wiara jest więc przekonaniem (belief), w którego strukturze wyróżnia się treść wyrażalną w zdaniach (sąd), akt uznania tej treści za prawdziwą (akt ten można nazwać „zaangażowaniem” aletycznym) oraz przedmiot wiary, którym jest stan rzeczy czyniący dane przekonanie prawdziwym. W tym sensie wiara jest klasą twierdzeń uznawanych w akcie zaangażowania propozycjonalnego przez kogoś za prawdziwe. Tak pojęta wiara religijna nie jest synonimem religii, lecz tylko jedną z części stanowiących złożoną i trudną do zdefiniowania całość.

\section{Racjonalność epistemiczna a filozofia języka Wittgensteina}

Koncepcja głosząca, że istnieją uniwersalne warunki racjonalności dla wszystkich rodzajów przekonań oraz że racjonalność przekonań podlega stopniowaniu, może budzić wątpliwości, jeżeli rozważy się poglądy Ludwiga Wittgensteina, dominujące, a w każdym razie bardzo wpływowe, zwłaszcza te z drugiego okresu jego twórczości, wyrażone głównie w Dociekaniach filozoficznych i innych pomniejszych pracach. Stąd nie dzi-

260 wi, że Kleszcz podjął się krytyki filozofii późnego Wittgensteina. Krytyka ta jest ważna $z$ trzech powodów. Po pierwsze, stanowi obronę logicznego racjonalizmu, będącego jednym z istotnych składników metafilozofii SLW, której on sam jest obrońcą. Po drugie, krytyka poglądów Wittgensteina wydaje się niezbędna dla obrony koncepcji racjonalności przekonań światopoglądowych zaproponowanej przez Kleszcza. I po trzecie, jest ważna w dyskusjach nad statusem religii i teologii, w tym teologii filozoficznej w szczególności.

Wittgenstein wystąpił $\mathrm{z}$ teza, że nie istnieje jeden wzorcowy system językowy. Istnieją natomiast rozmaite i różne od siebie "gry językowe" posiadające właściwe dla siebie kryteria racjonalności, a sam język może pełnić rozmaite funkcje (Wittgenstein 1972, cz. 1/7). Odmienne gry językowe różnią się od siebie celami i sposobami ich uprawiania, choć wszystkie można i należy traktować jako należące do rodziny gier językowych. Koncepcja ta implikuje, że nie ma jednego znaczenia, które można by przypisać danemu słowu poza kontekstem danej gry językowej. W konsekwencji nie ma też jednego typu reguł użycia słów i nie ma jednego typu błędów poza daną grą językową (Kleszcz 2007, s. 91). Dalej, charakteryzując stanowisko Wittgensteina, Kleszcz zauważa, że w sporze, w którym uczestniczą użytkownicy i przedstawiciele dwóch odmiennych systemów, nie można się odwołać do żadnych kryteriów zewnętrznych (neutralnych), ponieważ wszelkie kryteria obowiązują wyłącznie wewnątrz systemu. 
Nie można zastosować argumentacji, ponieważ nie ma jednolitych reguł i strategii argumentacyjnych obowiązujących w różnych systemach i grach językowych. Ilustracją tej sytuacji jest przykład sporu teisty z ateista, którego przedmiotem jest istnienie Boga. Przypomina ona różne gry z użyciem piłki i moment, w którym jeden z graczy zagrał ręką. Jeżeli - argumentuje Kleszcz - jeden z graczy utrzymuje, że zachowanie drugiego było niedozwolone, a drugi, że dozwolone, to rzeczywista niezgodność zachodzi między nimi tylko wtedy, gdy grają w tę samą grę (np. piłkę nożną lub siatkówkę). Nie ma więc żadnej niezgodności między gracza$\mathrm{mi}$, ponieważ obaj grają $\mathrm{w}$ różne gry, w których obowiązują odmienne reguły. Zdaniem Wittgensteina gdy występuje teista wierzący w Boga, Sąd Ostateczny itp. oraz ateista niewierzący w to wszystko, nie zachodzi sytuacja, w której między wiarą pierwszego i niewiarą drugiego zachodzi sprzeczność (believing the opposite). Ta różnica przekonań w kwestiach światopoglądowych i religijnych jest zupełnie odmiennym przypadkiem różnicy przekonań niż różnica w kwestiach dotyczących np. spraw życia codziennego.

Jeszcze dobitniej może konsekwencje teorii gier językowych są widoczne w przypadku języka religijnego. Język religijny ma zupełnie inne kryteria uzasadniania niż te obowiązujące w języku naukowym czy potocznym. W języku religijnym nie pojawia się zupełnie kwestia dowodzenia czy uzasadniania prawd wiary. Prawdy wiary nie są bowiem teoriami czy hipotezami naukowymi. Jedną z konsekwencji takiego rozumienia języka religii (i teologii) jest to, że osoba religijnie niezaangażowana, pozostająca poza wspólnotą religijną, nieuczestnicząca w praktykach religijnych i nieżyjąca według pewnej określonej formy życia, nie rozumie języka religijnego używanego przez osobę wierzącą. Zdaniem Wittgensteina przekonanie religijne (wiara $\mathrm{w}$ sensie $\mathrm{C}$ ) nie jest hipotezą poddawaną testom, ale odgrywa dominującą rolę w interpretacji życia i świata oraz w życiu człowieka wierzącego. Przekonania religijne odgrywają więc ogromnie ważną rolę egzystencjalna, której pozbawione są hipotezy i teorie naukowe. Między wiarą a nauką (wiedzą) zachodzi więc zasadnicza różnica. W przypadku przekonań religijnych nie dysponujemy żadnymi metodami rozstrzygania prawdziwości lub fałszywości tez (przekonań) religijnych. Nie są owe metody jednak do niczego potrzebne osobie wierzącej, ponieważ wiara polega na określonym sposobie życia i myślenia, a te nie wymagają żadnych naukowych uzasadnień. W tym ujęciu absurdem jest traktowanie systemu przekonań religijnych analogicznie do systemu przekonań naukowych. Słowo „wierzyć" na gruncie języka religijnego ma zupełnie inne znaczenie niż poza nim. Wiara w Boga oznacza określony sposób życia i odgrywa ona, jak sygnalizowaliśmy, doniosłą rolę $\mathrm{w}$ podejmowaniu decyzji o fundamentalnym znaczeniu dla życia 
jednostki. Przekonania naukowe (uznawane teorie i hipotezy z zakresu nauk przyrodniczych) nie odgrywają podobnej roli, choć ich status metodologiczny i epistemiczny wydaje się o wiele lepszy, co podkreśla, interpretując stanowisko Wittgensteina, Kleszcz (2007, s. 92). W przypadku osoby wierzącej, posługującej się językiem religijnym, mamy do czynienia, zdaniem Wittgensteina, $\mathrm{z}$ wiarą $\mathrm{w}$ pewien obraz, w którym pokłada się zaufanie, czy, jeszcze ogólniej mówiąc, na podstawie którego interpretacji reguluje się swoje życie. Myślenie wierzącego skupia się wokół tego obrazu, skupia jego uwagę i napomina go, skłaniając do określonego sposobu zachowania się (Kleszcz 2007, s. 94).

Wiara religijna obejmuje silne zaangażowanie osobiste wierzącego, niewystępujące np. w wypadku uczonego uznającego pewne twierdzenie. Uznanie przez uczonego określonego twierdzenia naukowego może nie wywoływać żadnych ważnych egzystencjalnie emocji ani nie mieć żadnego wpływu na jego sposób życia. Język religijny jest więc w ujęciu Wittgensteina głównie językiem obrazowym, wywołującym określone uczucia, postawy i determinującym sposób życia. Do istotnych konsekwencji takiej koncepcji języka religijnego, wynikającej z teorii języka jako gry, należy ta głosząca, że obowiązujące w języku naukowym czy nawet potocznym reguły falsyfikacji nie mają żadnego zastosowania $\mathrm{w}$ religii lub teologii. Nie mają więc zastosowania również kryteria racjonalności epistemicznej wprowadzone przez Kleszcza, o których była mowa wyżej. W konsekwencji język religijny, a także język teologii i metafizyki religijnej (i nie tylko takiej) nie mają żadnej wartości poznawczej. Ostatnia konkluzja jest zgodna ze stanowiskiem skrajnego empiryzmu w kwestii wartości poznawczej języka religijnego i ogólniej, filozoficznego.

Kleszcz rekonstruuje stanowisko skrajnego empiryzmu za pomoca następującego sylogizmu:

(1) Wszelki znaczący poznawczo język jest falsyfikowalny

(2) Język religijny nie jest falsyfikowalny

Zatem:

(3) Język religijny nie jest językiem poznawczo wartościowym (2007, s. 99).

Wniosek (3) należy rozumieć po prostu w ten sposób, że język religijny nie opisuje świata i nie dostarcza żadnej wiedzy o świecie.

Poddając krytyce filozofię języka "późnego" Wittgensteina i języka religijnego w szczególności, Kleszcz formułuje różnego rodzaju zarzuty. Wymieńmy kilka z nich. Teoria języka jako zbioru gier językowych jest niespójna, ponieważ implikuje relatywizm, a sam relatywizm jest niespójny i wobec tego nie jest racjonalny. Zarzut ten można rozumieć w ten sposób, że skoro wszystkie gry językowe mają własne reguły i nie ma żadnych standardów neutralnych dla oceny ich wartości logicznej oraz ich racjonalności, 
dotyczy to również samej teorii gier językowych Wittgensteina. Jest ona tylko jedną z gier językowych, w której pojęciem centralnym jest pojęcie "gry językowej", i nie zajmuje żadnej uprzywilejowanej pozycji w klasie teorii dotyczących języka, jego funkcji i natury. Jeśli ktoś ma inną koncepcję języka niż ta sugerowana przez Wittgensteina, może przy niej zostać i zupełnie zignorować koncepcję niewspółmiernych i nieporównywalnych wzajemnie języków (gier językowych). W przypadku języka religijnego, zauważa Kleszcz, nie jest również prawdą twierdzenie Wittgensteina, że centralnym składnikiem tego języka są obrazy. Kleszcz pisze:

Język religijny wyraża się za pomocą zróżnicowanych środków, m.in. takich jak: modele, symbole czy obrazy. Te ostatnie nie są więc, jak chciał Wittgenstein, jedynym środkiem wyrazu. Modele byłyby najogólniejszymi schematami interpretacji, które odwołując się do analogii, pozwalałyby przedstawić pewną trwałą strukturę świata, umożliwiając zarazem pewnego rodzaju falsyfikację (2007, s. 101).

Kolejny zarzut podniesiony wobec koncepcji Wittgensteina głosi, że nie jest prawdą, że osoby nieuczestniczące $\mathrm{w}$ życiu religijnym nie są $\mathrm{w}$ stanie zrozumieć znaczenia języka religijnego, którym posługują się osoby wierzące:

Język teologii danej religii może przecież rozumieć ktoś, kto nie podziela tez danej religii. Oznacza to zarazem odrzucenie stanowiska Wittgensteina, że w sytuacji tego, co nazywa on odrębnymi "grami językowymi", niemożliwe jest, w gruncie rzeczy, poddanie stanowiska spoza naszej "gry językowej” falsyfikacji. Na gruncie myśli Wittgensteina nie byłoby nigdy możliwe podważanie, czy w ogóle poddawanie krytyce tego, co jest przedmiotem czyjejś wiary lub niewiary (Kleszcz 2007, s. 101).

Nie jest również prawda, że wiara polega wyłącznie na zaangażowaniu i praktykowaniu pewnego sposobu życia i że treści propozycjonalne (określone tezy religijne, dogmaty itd.) nie mają żadnej wartości poznawczej:

Budzącym zasadnicze wątpliwości jest traktowanie przez Wittgensteina religii wyłącznie jako zaangażowania i konsekwentne uznawanie, że tez religii nie daje się zrozumieć wtedy, gdy nie angażujemy się na ich rzecz [...] Wiara np. w Boga oznaczałaby w konsekwencji nie tylko pewną postawę zaangażowania, ale także zawierałaby jako swój składnik, pewne przekonania co do Jego istoty (Kleszcz 2007, s. 103).

Wzmacniając siłę tego zarzutu, Kleszcz odwołuje się do trwającej od wielu wieków tradycji uzasadniania przekonań religijnych (wskazuje tu i w innych miejscach na filozofię patrystyczna, scholastykę, a zwłaszcza myśl św. Tomasza z Akwinu): 
Uznaje się, że wiara religijna (i jej tezy), aspirują do pewnego typu uzasadnienia (podawania racji). Racje takie, pomijając tutaj kwestie ich wartości próbuje się formułować od epoki patrystycznej poczynając. Jeżeli konsekwentnie przyjmiemy, że w wierze mamy do czynienia z elementami sądu, to dopuszcza to i czyni zrozumiałym próby argumentowania zarówno pro, jak i contra (Kleszcz 2007, s. 105).

W związku z powyższymi zarzutami i spostrzeżeniami dodaje, że:

Nie można więc mówić o całkowitej odporności przekonań religijnych na falsyfikację, choć zarazem trudno też mówić o możliwości ostatecznego ich obalenia. Przekonania w sferze religii ocenia się z punktu widzenia ich walorów poznawczych, ale także innych, np. etycznych czy praktycznych (Kleszcz 2007, s. 106).

Warto w tym kontekście przypomnieć, że falsyfikacja przekonań religijnych stanowiących treść światopoglądu mogłaby polegać na wykazaniu sprzeczności albo w systemie tych przekonań, albo pomiędzy określonymi tezami religijnymi a teoriami nauki. Taka procedura falsyfikacji przekonań religijnych $\mathrm{w}$ ramach koncepcji racjonalności epistemicznej Kleszcza, o czym była mowa w rozdziale 2 tego artykułu, jest właściwa, skoro głosi on pogląd, że nauka (w tym logika) jest normą negatywną dla światopoglądu, a zatem również dla tez/przekonań religijnych. Autor analizowanych $\mathrm{w}$ niniejszym tekście poglądów sam podaje tytułem egzemplifikacji możliwe uzasadnienie dla tezy religijnej i światopoglądowej (można ją również traktować jako tezę metafizyczną):

Argumentacja na rzecz pewnego systemu przekonań religijnych, np. teizmu [światopoglądu] mogłaby zmierzać do wskazania, że lepiej niż naturalizm wiąże on w pewną całość dane jakich dostarcza nam doświadczenie w tej sferze (Kleszcz 2007, s. 106).

\section{Atrybut wszechmocy Bożej a racjonalność epistemiczna}

Zrekonstruowana powyżej krytyka teorii gier językowych i teorii religii późnego Wittgensteina przeprowadzona przez Kleszcza czyni możliwą nie tylko obronę koncepcji racjonalności wiary, w tym racjonalności wiary religijnej w szczególności (wiary w sensie C), ale też otwiera pole dla formułowania racjonalnych argumentów na rzecz różnych szczegółowych tez w ramach określonego systemu metafizycznego czy światopoglądu. Doskonałą ilustracją tego, jak taka strategia argumentacyjna działa, są rozważania Kleszcza dotyczące różnych koncepcji Bożej wszechmocy 
(Kleszcz 2012, 2015). Autor, którego poglądy omawiamy, przedstawił po przeprowadzeniu niezbędnych analiz terminologicznych argumenty w obronie koncepcji ograniczonej wszechmocy Bożej. W jego przekonaniu za koncepcją wszechmocy ograniczonej przemawiają ważkie racje ${ }^{8}$ i w jej obronie formułuje on następujące argumenty. Uznanie tezy o nieograniczonej wszechmocy Bożej implikuje możliwość naruszania przez Boga praw logiki, w tym zasady sprzeczności. Jeśli bowiem niegraniczona wszechmoc Boga jest rozumiana właśnie tak, że Bóg może uczynić absolutnie wszystko, to możliwe jest, że może On wykonywać działania, których opisem są pary zdań logicznie sprzecznych (np. wszechmocny w tym sensie Bóg może spowodować, żeby coś istniało i nie istniało jednocześnie albo żeby istniał byt o wykluczających się własnościach, może też zmieniać przeszłość, prawa logiki i zasady moralne). Wszystko to może zrobić wszechmocny Bóg, jeśli wszechmoc polega na możliwości uczynienia absolutnie wszystkiego. Koncepcja takiej wszechmocy podważa zarówno racjonalność, której broni Kleszcz, jak i jest niezgodna z intuicją dotyczącą Bożej doskonałości, ponieważ dopuszcza, że Bóg może czynić zło. Może mieć również poważne konsekwencje praktyczne dla osób wierzących. Jeśli bowiem możliwe jest, że Bóg zmieni zasady moralne, które sam ustanowił, a jest to właśnie możliwe, skoro dla wszechmocy Bożej tak „naiwnie" rozumianej nic nie jest niemożliwe, to motywacja do przestrzegania aktualnie obowiązujących zasad Dekalogu może być mniejsza. Poza tym Kleszcz stwierdza, że klasyczne, racjonalistyczne i filozoficznie wyrafinowane pojęcie wszechmocy Bożej (ograniczonej), której bronił św. Tomasz z Akwinu, a współcześnie broni np. Richard Swinburne, do którego poglądów Kleszcz wprost nawiązuje, nie sprawia, że Bóg jest bytem mniej zasługującym na cześć religijna, niż byłoby to w przypadku wszechmocy „nijak nieograniczonej” (Kleszcz 2015, s. 211). W swojej argumentacji za tezą o ograniczonej wszechmocy Bożej podkreśla on również, że tradycja teologiczna oraz większość myślicieli badających kwestię Bożych atrybutów i natury Boga również opowiadają się za koncepcją wszechmocy ograniczonej. Tylko nieliczni bronili lub bronią obecnie doktryny wszechmocy nieograniczonej - w przeszłości byli to np. P. Damiani, Kartezjusz, a współcześnie Stanisław Judycki (Kleszcz 2015, s. 212). Jednakże należy też mocno podkreślić, że broniąc doktryny ograniczonej wszechmocy Bożej, Kleszcz zdaje sobie doskonale sprawę, że narzucenie naturze Boga pojęć, schematów i ogólnie mówiąc, konstrukcji umysłu ludzkiego, jest

${ }^{8}$ Kleszcz definiuje wszechmoc Bożą następująco: „Istota wszechmocna to taka istota, która jest w stanie sprawiać (aktualizować) każdy logicznie możliwy, przygodny stan rzeczy X, przy założeniu, iż nie jest ona przekonana, że ma nadrzędne racje, by powstrzymać się od sprawienia (aktualizowania) X" (2012, s. 45; 2015, s. 206). 
niezwykle ryzykowne i nie ma licznych zwolenników wśród przedstawicieli zachodniego teizmu, z którym, w naszym przekonaniu, Kleszcz wyraźnie sympatyzuje. Stwierdza on zdecydowanie: „[P]odkreślić muszę, że nie oznacza to, że Boga wiąże logika klasyczna w całości lub jakaś logika nieklasyczna" (2012, s. 51).

Zagadnienie Bożej wszechmocy omawiamy w kontekście racjonalności przekonań dla ilustracji tego, jak koncepcja racjonalności przekonań Kleszcza funkcjonuje w praktyce filozoficznej. Z poczynionych powyżej uwag i na podstawie wcześniejszej rekonstrukcji poglądów Autora dotyczących gradualistycznej koncepcji racjonalności przekonań można wnioskować, że możliwa i potrzebna jest argumentacja w obrębie metafizyki, teologii i tez światopoglądowych. Możliwa jest ocena stopnia racjonalności poszczególnych tez metafizycznych, gdy rozważy się racje przemawiające za i przeciw nim. W przypadku tezy o ograniczonej wszechmocy Boga można podać bardzo silne racje za tą tezą i bardzo silne racje przeciwko tezie z nią sprzecznej (o nieograniczonej wszechmocy Boga). Racją zasadniczą za koncepcją Tomasza (bliską Kleszczowi) jest to, że doktryna ta nie implikuje sprzeczności i sprzeczność wyklucza, a zarazem nie umniejsza Bożego majestatu, a nawet być może lepiej go przedstawia, eliminując możliwą w ramach tezy opozycyjnej arbitralność i chwiejność Bożej woli. Rozważany przykład Bożej wszechmocy pokazuje, że również w ramach przekonań o niższym stopniu racjonalności niż naukowe, ale wciąż racjonalnych, możliwe są dyskusja i argumentacja, a nawet wydaje się, że możliwa jest falsyfikacja. Jeśli bowiem pewna teza filozoficzna czy światopoglądowa implikuje sprzeczność, jest nie tylko nieracjonalna, ale i musi być po prostu fałszywa. Wydaje się, że taką tezą byłaby, zdaniem Kleszcza, właśnie teza o nieograniczonej wszechmocy Bożej. Jednakże najważniejszy wniosek, jaki należy wysnuć z powyższej, z konieczności bardzo zwięzłej rekonstrukcji poglądów Kleszcza na temat Bożej wszechmocy, dotyczy istnienia pewnych uniwersalnych kryteriów racjonalności, które mogą i powinny być stosowane zarówno w dyskusjach filozoficznych, jak i formowaniu tez światopoglądowych. Zatem jeśli wiara w sensie C (wiara religijna) spełnia kryterium niesprzeczności, może być uznana za racjonalną.

\section{Racjonalność nauki}

Jak wyżej wspomniano, kryterium racjonalności dla tez/przekonań filozoficznych i światopoglądowych jest, poza ich niesprzecznością logiczną, niesprzeczność z teoriami nauki współczesnej, której metody badawcze, standardy precyzji, ścisłości, wrażliwość na falsyfikację, czyli 
sprawdzenie wartości poznawczej i możliwości eliminowania fałszu, są wyższe niż w wypadku filozofii i przekonań światopoglądowych. Jednakże w filozofii poznania i wiedzy Kleszcza ten silny nacisk na udział nauki $\mathrm{w}$ epistemicznym uprawomocnianiu racjonalności przekonań pozanaukowych nie prowadzi w żadnym wypadku do scjentyzmu jako poglądu, że poznanie naukowe jest jedynym wartościowym poznaniem ${ }^{9}$. Ilustrując swój pogląd, omawiany przez nas Autor powołuje się na opinie innych wybitnych współczesnych uczonych, cytując wypowiedzi Nicholasa Reschera, Mariana Przełęckiego i Bogusława Wolniewicza. Warto niektóre z nich tutaj przytoczyć. I tak Rescher stwierdza, że

Nauka nie ma wyłącznego prawa do bycia wiedzą, zakres jej dociekań jest znacznie węższy niż zakres dociekań rozumu jako takiego. Nauka pośród różnych odmian wiedzy, jest tylko jedną z nich (cyt. za: Kleszcz 2017, s. 73; przekład D.Ł. $)^{10}$.

\section{Wolniewicz zaś pisze:}

Filozofia nie jest nauką [...] Świat nie kończy się wraz z nauka, a żyć w nim i myśleć trzeba. [...] Filozofia jest dziś tym, czym zawsze była: próbą racjonalnego orientowania się w świecie, gdzie brak wiedzy pozytywnej (cyt. za: Kleszcz 2017, s. 91).

Kleszcz nie tylko dostrzega ograniczony zakres i niekompletność wiedzy naukowej, ale też wskazuje, że zawiera ona elementy wiary, przy czym przez wiarę rozumieć tu należy przekonania w zaproponowanym przez niego sensie A i B. Radykalny intelektualizm w rozumieniu nauki nie daje się utrzymać, ponieważ jej uprawianie wymaga od uczonych uznawania przekonań nieuzasadnionych, np. uznawania na podstawie autorytetu wyników badań przeprowadzonych przez innych badaczy lub wiary $\mathrm{w}$ rzetelność i niezawodność urządzeń pomiarowych. Istotną rolę w formułowaniu założeń i hipotez badawczych mogą odgrywać również rozmaite presupozycje metafizyczne, np. nieweryfikowalne empirycznie przekonanie o celowym ustroju wszechświata. Można wprawdzie zweryfikować rzetelność badaczy podających swoje wyniki, ale postęp

${ }^{9}$ Warto podkreślić, że w epistemologii Kleszcza niesprzeczność z twierdzeniami nauki nie jest uzasadnieniem dla tezy filozoficznej czy przekonania światopoglądowego, lecz tylko warunkiem ich racjonalności epistemicznej. Uzasadnieniem dla tezy filozoficznej jest podanie pewnych racji. Racją uzasadniającą może być np. argument dedukcyjny, jak w dowodzie ontologicznym na istnienie Boga w jednej z jego modalnych wersji na podstawie tezy rachunku S5, albo może nią być wykazanie siły eksplanacyjnej hipotezy teistycznej, co sugeruje, jak była o tym już wcześniej mowa, Kleszcz.

${ }^{10}$ Fizyka np. nie docieka, dlaczego istnieją prawa fizyki (Kleszcz 2017, s. 82). 
w nauce możliwy jest również dlatego, że istnieje wiara $\mathrm{w}$ wartość poznawczą wyników osiągniętych przez innych (wiara typu A).

Wnikliwą analizę systemu twierdzeń naukowych i ich statusu epistemicznego znajdujemy w artykule Kleszcza poświęconego myśli Gastona Milhauda, francuskiego uczonego i wybitnego prekursora konwencjonalizmu jako stanowiska w filozofii nauki. Milhaud, badając dzieje nauki, wykazuje, że bardzo istotną rolę $\mathrm{w}$ formułowaniu teorii naukowych, zwłaszcza o wysokim stopniu ogólności i komplikacji, odgrywają subiektywna inicjatywa, przypadek, indywidualna wyobraźnia i spontaniczna kreatywność poszczególnych uczonych (Kleszcz 2019, s. 57). Kleszcz solidaryzuje się z tym wybitnym reprezentantem francuskiego konwencjonalizmu w krytyce pozytywistycznego dogmatyzmu, pisząc, że:

Nie daje się bowiem podtrzymać pozytywistyczna teza, iż nauka to połączenie komponenty empirycznej i logiki współczesnej, skoro decyzje racjonalne przekraczają te dwa czynniki i istotną rolę gra to, co nazywa się elementem wolnej kreacji, spontaniczności. Te uwagi i nastawienie krytyczne wobec pozytywizmu wszelakiego zdają się uzasadnione, zwłaszcza w świetle późniejszych dyskusji i krytyki tego nurtu. W mej opinii to stanowisko, jakie u niego [Milhauda] znajdujemy w odniesieniu do pozytywizmu mogłoby być zasadnie podtrzymywanym, także dzisiaj, czyli sto lat po śmierci francuskiego konwencjonalisty $(2019, \text { s. 59) })^{11}$.

Te wypowiedzi zarówno samego Kleszcza, jak i autorów, z których poglądami się on zgadza, świadczą o bardzo wyważonej i wysubtelnionej ocenie statusu wiedzy naukowej i jej relacji do innych rodzajów poznania oraz relacji do szeroko pojętej wiary. Może się w tym kontekście nasuwać pytanie: czy wobec pojawiających się wyraźnie racji za osłabieniem uprzywilejowanej pozycji nauki w stosunku do innych form poznania, obejmujących również poznanie pozanaukowe, takie jak filozofia czy wiara religijna (C) lub światopogląd, nauka słusznie jest traktowana jako norma negatywna dla wiary (filozofii, teologii, religii)? Innymi słowy, czy niesprzeczność tez filozoficznych lub przekonań religijnych z teoriami nauki współczesnej winna rzeczywiście stanowić kryterium racjonalności dla wiary (światopoglądu)?

Ostatnie pytanie można jeszcze wyostrzyć, przywołując słynny argument Alvina Plantingi przeciwko naturalizmowi. Argument Plantingi, najogólniej ujmując, polega na tym, że jeśli uznamy teorię ewolucji za naukową teorię wyjaśniającą $\mathrm{w}$ pełni pochodzenie i naturę człowieka i jego zdolności poznawczych, to nie mamy wystarczających podstaw, aby sądzić, że nasze przekonania o świecie są prawdziwe. Zgodnie z teorią

\footnotetext{
${ }^{11}$ Warto przypomnieć, że Milhaud zmarł w Paryżu w 1918 r.
} 
ewolucji, będącą dziś standardową i powszechnie uznawaną teorią naukową dotyczącą pochodzenia gatunków, ludzkie władze poznawcze są rezultatem bezcelowych mutacji i doboru naturalnego organizmów walczących o przetrwanie. Treść przekonań, jakie mamy na temat świata, nie ma istotnego znaczenia dla naszego zachowania, które jest ewolucyjnie zaprogramowane w taki sposób, by maksymalizować szanse na przetrwanie biologiczne, a nie na poznawanie prawdy. Plantinga argumentuje, że przy założeniu naturalizmu metafizycznego (istnieją tylko przyroda i jej wytwory) oraz ewolucjonizmu prawdopodobieństwo, że nasze władze poznawcze są rzetelne $w$ tym sensie, że najczęściej prowadzą nas do poznania prawdy, jest niskie, znacznie niższe niż prawdopodobieństwo, że prowadzą nas do fałszu. Istnieje więc powód do wątpienia w prawdziwość naszych przekonań. Możemy działać skutecznie mimo posiadania fałszywych przekonań (Plantinga 2019). Inaczej wyglądałaby sytuacja, zdaniem Plantingi, gdyby przyjąć, że człowiek nie jest ślepym i przypadkowym wytworem przyrody, która sama jest bezcelowa i bezrozumna, lecz jest dziełem Bożym. Innymi słowy, jeśli nasze przekonanie (metaprzekonanie), że nasze przekonania są przeważnie prawdziwe, ma być racjonalne, należy przyjąć, że istnieje Bóg, który pośrednio czy bezpośrednio spowodował powstanie gatunku ludzkiego i każdego ludzkiego umysłu.

\section{Konkluzje}

Epistemologia i, ogólniej mówiąc, filozofia Kleszcza radzą sobie z argumentem antynaturalistycznym Plantingi bardzo dobrze, ponieważ sama tezy naturalizmu metafizycznego nie zawiera. Nauka może być rzetelnym, a nawet najrzetelniejszym narzędziem poznawania świata przyrody i dlatego powinna być ona kryterium racjonalności dla przekonań pozanaukowych. Tak być powinno, ponieważ, według teizmu, zarówno świat, jak i ludzkie zdolności poznawcze zostały stworzone przez wszechmocnego i doskonale dobrego Boga. Byt o takich własnościach daje nam najwyższe możliwe gwarancje, że nasze poznanie, w tym poznanie naukowe, jest rzetelne i kieruje się ku prawdzie. Warto w tym miejscu przypomnieć myśl wielkiego racjonalisty i matematyka Gottfrieda W. Leibniza o tym, że cały świat jest dla człowieka wierzącego zbiorem znaków myśli Bożej (cum Deus calculat et cogitationem exercet, mundus fit). Samo objawienie poucza, że tym lepiej poznajemy Boga, im lepiej poznajemy świat. W kontekście tej myśli można powiedzieć, że nauki szczegółowe odgrywają ważną rolę w budowaniu i wzbogacaniu o nowe treści światopoglądu religijnego i że, jak argumentuje Kleszcz, wiara, w tym wiara religijna, jest racjonalna, a w każdym razie może być racjonalna. 
Racjonalna jest taka wiara, która spełnia określone kryteria racjonalności, ale same te kryteria można racjonalnie formułować na gruncie teizmu, przyjmując światopogląd, którego fundamentem jest twierdzenie, że istnieje wszechmocna i doskonale dobra osoba, stwórca tego oto świata, w którym żyjemy i uprawiamy badania naukowe. Osobę tę w tradycji metafizycznej i religijnej nazywa się Bogiem. Wydaje się, że takie właśnie stanowisko jest bliskie poglądom Kleszcza, który, przypomnijmy jeszcze raz, stwierdza, że:

Argumentacja na rzecz pewnego systemu przekonań religijnych, np. teizmu [światopoglądu] mogłaby zmierzać do wskazania, że lepiej niż naturalizm wiąże on w pewną całość, dane jakich dostarcza nam doświadczenie w tej sferze (2007, s. 106).

W naszym przekonaniu argumentacja taka nie tylko może zmierzać do wskazania, że teizm lepiej niż ateizm wiąże w pewną całość dane, które dostarcza nam doświadczenie, ale też może ona wykazać, że światopogląd teistyczny lepiej niż ateizm zaspokaja najgłębsze ludzkie pragnienia, takie jak pragnienie sprawiedliwości, prawdy, dobra i piękna. Kleszcz, formułując swoją gradualistyczną koncepcję epistemicznej racjonalności przekonań, dostarcza narzędzia teoretyczne i ukazuje możliwości obrony racjonalnej wiary obejmującej fundamentalne egzystencjalnie prawdy metafizyczne i religijne.

\section{Bibliografia}

Ajdukiewicz K. (1934), Logistyczny antyirracjonalizm w Polsce, „Przegląd Filozoficzny” 37, 4, s. 399-408.

Cherniak C. (1986), Minimal Rationality, The MIT Press, Cambridge.

Dąmbska I. (1938), Irracjonalizm a poznanie naukowe, „Kwartalnik Filozoficzny” 14, s. 83-118.

Kleszcz R. (1998), O racjonalności. Studium epistemologiczno-metodologiczne, Wydawnictwo Uniwersytetu Łódzkiego, Łódź.

Kleszcz R. (2007), O rozumie i wartościach, Wydawnictwo Wyższej Szkoły Humanistyczno-Ekonomicznej w Łodzi, Łódź.

Kleszcz R. (2012), Logika, wszechmoc, Bóg, „Filo-Sofija” 19, s. 37-52.

Kleszcz R. (2013), Metoda i wartości, Wydawnictwo Naukowe Semper, Warszawa.

Kleszcz R. (2015), O filozofii religii, wszechmocy Boga oraz ograniczoności naszego języka, „Filo-Sofija" 30, s. 199-214.

Kleszcz R. (2017), Uwagi o granicach poznania naukowego, „Filo-Sofija” 37, s. 73-92.

Kleszcz R. (2019), Gaston Milhaud - filozofia, nauka, racjonalność, „Przegląd Filozoficzny - Nowa Seria" 3(111), s. 45-62.

Łukasiewicz J. (2013), Pamiętnik, [w:] J. Jadacki, P. Surma (red.), Jan Łukasiewicz. Pamiętnik. Wydawnictwo Naukowe Semper, Warszawa.

Odoj E. (2015), Spory epistemologiczne we współczesnej filozofii religii, [w:] S. Janeczek, A. Starościc (red.), Epistemologia, Wydawnictwo KUL, Lublin, s. 415-440. 
Plantinga A. (2019), Ewolucyjny argument przeciwko naturalizmowi, [w:] P. Gutowski, M. Iwanicki (red.), Teizm, ateizm i religia. Najnowsze spory w analitycznej filozofii religii, Wydawnictwo KUL, Lublin, s. 587-601.

Salamucha J. (1997), Teologia i filozofia, [w:] J. Jadacki, K. Świętorzecka (red.), Wiedza i wiara. Wybrane pisma filozoficzne, Towarzystwo Naukowe Katolickiego Uniwersytetu Lubelskiego, Lublin, s. 47-50.

Salamucha J. (1997a), Struktura katolickiego poglądu na świat, [w:] J. Jadacki, K. Świętorzecka (red.), Wiedza i wiara. Wybrane pisma filozoficzne, Towarzystwo Naukowe Katolickiego Uniwersytetu Lubelskiego, Lublin, s. 41-47.

Tatarkiewicz W. (1971), Droga do filozofii i inne rozprawy filozoficzne. Pisma zebrane, PWN, Warszawa.

Twardowski K. [1929] (1965), Przemówienie wygłoszone na obchodzie dwudziestopięciolecia Polskiego Towarzystwa Filozoficznego we Lwowie dnia 12 lutego 1929, [w:] idem, Wybrane pisma filozoficzne, PWN, Warszawa, s. 379-384.

Twardowski K. (1965), Wybrane pisma filozoficzne, PWN, Warszawa.

Wittgenstein L. (1972), Dociekania filozoficzne, PWN, Warszawa.

Woleński J. (1985), Filozoficzna Szkoła Lwowsko-Warszawska, PWN, Warszawa.

Streszczenie: O racjonalności przekonań światopogladowych w ujęciu Ryszarda Kleszcza

Artykuł przedstawia stanowisko epistemologiczne Ryszarda Kleszcza, a w szczególności jego koncepcję racjonalności przekonań. Teza, której staram się bronić, głosi, że koncepcja Kleszcza nawiązuje do idei logicznego racjonalizmu typowej dla Szkoły Lwowsko-Warszawskiej, ale też w oryginalny sposób rozwija i modyfikuje pogląd broniony przez Kazimierza Twardowskiego i jego uczniów. Kleszcz argumentuje za teza, że binarna klasyfikacja przekonań na racjonalne i nieracjonalne jest trudna do utrzymania i że bardziej uzasadnione jest wprowadzenie stopni racjonalnością przekonań. Według tej koncepcji racjonalne w pewnym stopniu są również przekonania metafizyczne i religijne.

Słowa kluczowe: epistemologia, przekonanie, nauka, racjonalność, metafizyka

Summary: On the Rationality of Worldview Beliefs According to Ryszard Kleszcz

The paper discusses Ryszard Kleszcz's epistemological views, with the focus on his conception of rationality of beliefs. It aims to show that Kleszcz has adopted many of the ideas of logical rationalism typical of the Lvov-Warsaw School, but these ideas have been developed and significantly modified in his works. Kleszcz argues that the binary division of beliefs into rational and irrational is difficult to defend, and it is more justified and practicable to hold that belief's rationality is gradable; thus, metaphysical and religious beliefs could be - to a certain degree - rational as well.

Keywords: epistemology, belief, science, rationality, metaphysics 